\title{
Eksperimentasi Pembelajaran Daring Dengan Video Conference Pada Program Studi Teknik Informatika di Masa Pandemi
}

\author{
Siti Aminah ${ }^{*}$, Nira Radita ${ }^{2}$, Sugeng Widodo ${ }^{3}$ \\ ${ }^{1}$ Program Studi Teknik Informatika, Sekolah Tinggi Informatika \& Komputer Indonesia, Malang, Jawa Timur \\ ${ }^{2,3}$ Program Studi Manajemen Informatika, Sekolah Tinggi Informatika \& Komputer Indonesia, Malang, Jawa \\ Timur \\ Email: ${ }^{1 *}$ sitiaminah@stiki.ac.id, ${ }^{2}$ niraradita@stiki.ac.id, ${ }^{3}$ sugeng@stiki.ac.id
}

(Naskah masuk: 7 Jan 2021, direvisi: 1 Feb 2021, diterima: 3 Feb 2021)

\begin{abstract}
Abstrak
Masa pandemi Covid-19 menyebabkan perubahan strategi pembelajaran dari offline menjadi online. Pembelajaran online ini bukan merupakan hal baru, namun pembelajaran online pada masa pandemi sangat berbeda karena pembelajaran harus dilakukan full daring selama 1 semester. Tujuan dari penelitian ini adalah untuk mengetahui pengaruh penerapan video conference dalam pembelajaran sinkronus yang dilakukan secara online. Penelitian ini merupakan penelitian eksperimentasi dengan populasi mahasiswa Teknik Informatika STIKI, dengan pengambilan sampel secara random pada mahasiswa yang menempuh mata kuliah bersama dan mata kuliah keahlian. Analisis data yang digunakan adalah Uji Mann Whitney. Hasil dari penelitian ini adalah tidak ada perbedaan hasil belajar yang diukur dari nilai posttest mahasiswa antara pembelajaran daring dengan menggunakan video conference dan LMS Moodle yang dikembangkan di STIKI tanpa menggunakan video conference pada mata kuliah bersama. Sedangkan pada mata kuliah keahlian ada perbedaan hasil belajar yang diukur dari nilai posttest mahasiswa antara kegiatan perkuliahan daring dengan menggunakan video conference dan kegiatan daring dengan Moodle saja tanpa menggunakan video conference. Pembelajaran melalui video conference tidak selalu berpengaruh pada hasil belajar, namun ada beberapa faktor lain yang mempengaruhi, seperti tingkat kesulitan materi dan ketertarikan mahasiswa untuk mempelajari materi.
\end{abstract}

Kata Kunci: e-learning, uji mann whitney, video konferensi, matematika, teknik informatika

\section{Experimentation of an Online Learning with Video Conference in Informatics Student During Pandemic}

\begin{abstract}
During the Covid-19 pandemic, the learning strategy changed from offline to online. Online learning is not something new, but online learning during a pandemic is very different because learning must be done online for 1 semester. The purpose of this study was to determine the effect of the application of video conferencing in online synchronous learning. This research is an experimental study with a population of STIKI Informatics students, with random sampling of students taking joint courses and expertise courses. The data analysis used is the Mann Whitney test. The result of this study is that there is no difference in student learning outcomes with video conference learning and learning in joint courses. While in programming courses there are differences in student learning outcomes with and without video conference. The results of this analysis are measured through the students' posttest scores. Learning through video conferencing does not always affect learning outcomes, but there are several other factors that influence it, such as the level of difficulty of the material and student interest in learning the material.
\end{abstract}

Keywords: e-learning, mann whitney test, video conference, mathematic, informatic 


\section{PENDAHULUAN}

Pada tahun 2020, sindroma pernapasan akut berat virus korona 2 (SARS-CoV-2) menyebabkan penyakit virus korona 2019 (Covid-19) yang hingga 27 Desember 2020 telah menginfeksi 713.365 penduduk Indonesia dengan 21.237 orang di antaranya telah meninggal dunia [1]. Untuk memperlambat laju penyebaran virus tersebut, beberapa kebijakan dikeluarkan oleh pemerintah. Salah satunya adalah dengan mempraktikkan social distancing atau menjaga jarak sosial [2]. Upaya lainnya yang dilakukan oleh pemerintah yaitu memberi komando agar pegawai yang berusia lebih dari 50 tahun untuk bekerja dari rumah [3]. Sebagai tanggapan atas hal tersebut, Kemendikbud menetapkan dua prinsip kebijakan pendidikan di masa pandemi Covid-19 yang di antaranya adalah memprioritaskan kesehatan dan keselamatan peserta didik, pendidik, tenaga kependidikan, keluarga, dan masyarakat media [4]. Sebagai salah satu perguruan tinggi IT di Kota Malang, STIKI Malang memenuhi prinsip kebijakan pendidikan tersebut dengan menjalankan kegiatan pembelajaran secara daring.

Kegiatan pembelajaran secara daring pada masa pandemi Covid-19 ini bukan merupakan kegiatan perkuliahan daring pertama yang dilaksanakan di STIKI. Sebelumnya, pada tahun 2017 beberapa mata kuliah sudah diajarkan secara daring melalui sistem pembelajaran daring (SPADA) Indonesia. Perbedaan yang nyata adalah komposisi antara kegiatan tatap muka dengan kegiatan online. Pada pelaksanaan sebelumnya kegiatan online hanya dibatasi maksimal setengah dari jumlah seluruh pertemuan selama satu semester. Sedangkan pada masa pandemi Covid-19 kegiatan online dilakukan pada seluruh pertemuan selama satu semester. Kegiatan perkuliahan online dilakukan baik secara sinkronus maupun asinkronus. Selain itu, STIKI Malang juga menetapkan kebijakan tambahan dalam pelaksanaan kegiatan perkuliahan secara online yaitu dengan melaksanakan kegiatan sinkronus melalui video conference selama minimal 4 pertemuan dari jumlah seluruhnya 14 pertemuan selama satu semester.

Penelitian ini dilakukan dengan tujuan untuk mengetahui pengaruh penerapan video conference dalam pembelajaran sinkronus yang dilakukan secara online. Sebelumnya, sudah pernah dilakukan kajian yang menyimpulkan bahwa baik kegiatan pembelajaran tatap muka maupun video conference sama-sama mampu meningkatkan mutu pembelajaran, namun persentase peningkatan mutu pembelajaran dengan kegiatan tatap muka lebih besar daripada kegiatan online dengan video conference [5]. Hal itu bertentangan dengan penelitian Upshaw [6] yang hasil analisis datanya secara statistik tidak menunjukkan perbedaan yang signifikan, namun rata-rata nilai dari kelompok kontrol (kegiatan pembelajaran dengan video conference) mengalami peningkatan yang lebih besar daripada kelompok eksperimen (kegiatan pembelajaran tatap muka). Kegiatan pembelajaran secara online dengan video conference di STIKI Malang dilakukan dengan bantuan aplikasi Zoom Meeting atau Google Meet. Penggunaan aplikasi Zoom Meeting tidak begitu efektif, namun lebih baik karena komunikasi antara individu dilakukan secara lisan dibandingkan penggunaan aplikasi pembelajaran yang melakukan kegiatan komunikasi secara tertulis [7]. Sebaliknya, penggunaan Google Meet dapat mengatasi proses asistensi praktikum secara langsung dan presentasi, tanya jawab, dan diskusi langsung dapat tersampaikan [8]. Secara umum, kegiatan pembelajaran dengan video conference lebih efektif, interaktif, dan dapat mendukung pelaksanaan pembelajaran jarak jauh [9]. Dari beberapa penelitian tersebut, disimpulkan bahwa kegiatan pembelajaran dengan video conference lebih baik daripada kegiatan perkuliahan secara tradisional, namun masih diperlukan kajian apakah hal tersebut berlaku pula jika dibandingkan dengan kegiatan pembelajaran online secara asinkronus berbantuan aplikasi pembelajaran lainnya yang dalam penelitian ini adalah dengan menggunakan Learning Management System (LMS) Moodle versi 3.3. LMS pada STIKI disebut dengan E-belajar. E-belajar ini dapat diakses oleh dosen dan mahasiswa STIKI di http://ebelajar.stiki.ac.id/ seperti terlihat pada Gambar 1.

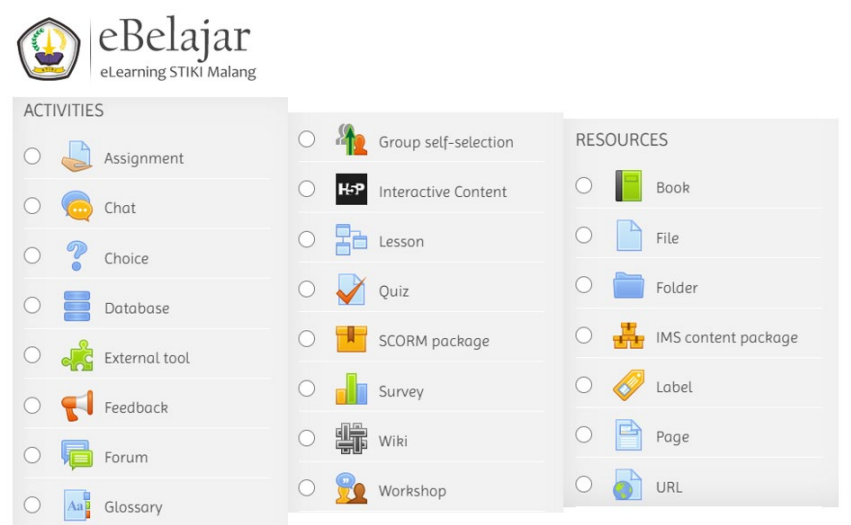

Gambar 1. Activities dan Resources yang Tersedia Pada E-Belajar, Moodle yang Dikembangkan di STIKI Malang

Kegiatan perkuliahan daring secara asinkronus yang dilaksanakan pada penelitian ini menggunakan fitur assignment, forum, interactive content, dan quiz. Pada fitur assignment, mahasiswa diberikan tugas dengan soal essay yang jawabannya bisa diunggah sistem. Fitur forum digunakan sebagai media diskusi antar mahasiswa dengan mahasiswa ataupun dosen dengan mahasiswa. Pada fitur interactive content, materi perkuliahan bisa disajikan dalam bentuk video dengan disisipi kuis yang berbentuk single choice set, multiple choice, true/false, fill in the blanks, drag and drop, mark the words, drag text, dan crossroads. Sedangkan pada fitur quiz, dosen menyajikan soal yang berupa soal pilihan ganda, jawaban singkat, mencocokkan, atau benar salah. Sumber belajar disajikan dalam bentuk buku digital, file materi, slide, ataupun video pembelajaran.

Perbedaan lainnya yang nampak adalah waktu kegiatan belajar. Untuk pembelajaran pada E-belajar, pembelajaran setiap seminggu sekali, kegiatan belajar diberikan waktu lebih lama, antara 1 hari - 1 minggu. Mahasiswa bisa mengerjakan kapan saja sesuai dengan waktu yang diberikan oleh dosen. Sedangkan untuk pembelajaran video conference di STIKI menggunakan Google Meet atau Zoom Meeting. Pada saat video conference, dosen dan mahasiswa harus hadir virtual dalam 1 waktu sesuai jadwal kuliah. Pada saat video 
conference, dosen menjelaskan melalui PPT atau melakukan coding secara live atau penjelasan melalui bahan ajar lainnya secara langsung.

\section{METODOLOGI PENELITIAN}

Penelitian ini adalah penelitian eksperimen. Desain eksperimen pada penelitian ini adalah Desain Faktorial (Factorial Design). Desain ini merupakan elaborasi dari desain true-experimental. Populasi dari penelitian ini adalah mahasiswa Teknik Informatika STIKI Malang. Sampel dari penelitian ini yaitu hasil belajar mahasiswa STIKI yang mengambil mata kuliah bersama dan mata kuliah keahlian dari berbagai kelas di tahun ajaran ganjil 2020/2021. Terdapat 2 sampel yang saling bebas yaitu hasil belajar mahasiswa setelah pembelajaran dengan video conference dan hasil belajar mahasiswa setelah pembelajaran melalui E-belajar. Pengambilan sampel untuk kelompok mata kuliah bersama, dilakukan secara random pada 20 mahasiswa yang mengikuti mata kuliah Statistika atau Matematika Diskrit. Pengambilan sampel untuk kelompok mata kuliah keahlian, dilakukan secara random pada 20 mahasiswa yang mengikuti mata kuliah keahlian, yaitu Desain Web atau Desain Grafis.

Teknik pengumpulan data pada penelitian ini dengan urutan sebagai berikut:

1. Mengumpulkan data berdasarkan 2 kelompok, yaitu mata kuliah bersama dan mata kuliah keahlian.

2. Untuk kelompok mata kuliah bersama, dilakukan pengumpulan data secara random dari 20 mahasiswa yang menempuh mata kuliah Statistika dan telah melaksanakan pembelajaran melalui video conference. Data ini sebagai sampel ke-1. Sedangkan sampel ke-2 diperoleh dari hasil belajar 20 mahasiswa pada mata kuliah Matematika Diskrit dan telah melaksanakan pembelajaran melalui E-belajar. Materi yang disampaikan pada E-belajar berupa materi dalam bentuk file PDF yang dibaca secara mandiri.

3. Untuk kelompok mata kuliah keahlian, dilakukan pengumpulan data secara random dari 20 mahasiswa yang menempuh mata kuliah Desain Web dan Desain Grafis telah melakukan pembelajaran secara video conference, sebagai sampel ke-1. Untuk sampel ke-2, diambil dari 20 hasil belajar mahasiswa yang telah menempuh Desain Grafis melalui pembelajaran E-belajar.

Pengumpulan data sampel diatas akan dikelompokkan seperti pada Tabel 1 .

Tabel 1. Pengelompokan Data dan Pengkategorian Data

\begin{tabular}{|c|c|c|c|}
\hline \multicolumn{4}{|c|}{ Sampel } \\
\hline $\begin{array}{c}\text { Variabel } \\
\text { Eksperimen }\end{array}$ & $\begin{array}{l}\text { Kelompok } \\
\text { Mata Kuliah }\end{array}$ & \multicolumn{2}{|c|}{ Media Pembelajaran } \\
\hline Variabel Bebas & & E-belajar & $\begin{array}{l}\text { Video } \\
\text { Conference }\end{array}$ \\
\hline \multirow[t]{2}{*}{$\begin{array}{l}\text { Variabel Teri } \\
\text { kat (Hasil } \\
\text { Belajar) }\end{array}$} & $\begin{array}{l}\text { Mata Kuliah } \\
\text { Bersama } \\
(\mathrm{MKB}) \\
\end{array}$ & $\begin{array}{l}\text { Kelompok } 1 \\
\text { (Matematika } \\
\text { Diskrit) }\end{array}$ & $\begin{array}{l}\text { Kelompok } 2 \\
\text { (MK Statistika) }\end{array}$ \\
\hline & $\begin{array}{l}\text { Mata Kuliah } \\
\text { Keahlian } \\
\text { (MKK) }\end{array}$ & $\begin{array}{l}\text { Kelompok } 3 \\
\text { (MK Desain } \\
\text { Web) }\end{array}$ & $\begin{array}{l}\text { Kelompok } 4 \\
\text { (MK Desain } \\
\text { Grafis) }\end{array}$ \\
\hline
\end{tabular}

Analisis data yang digunakan pada penelitian ini adalah sebagai berikut:

1. Pengkategorian data sampel. Untuk data dengan kategori 1 adalah nilai mahasiswa yang telah melakukan pembelajaran video conference. Untuk data dengan kategori 2 adalah nilai mahasiswa yang telah melakukan pembelajaran melalui E-belajar.

2. Melakukan uji normalitas pada kedua sampel pada tiap kelompok. Karena data dari masing tiap kelompok totalnya sebanyak 40 data, maka data dikatakan berukuran kecil, sehingga dilakukan uji kenormalan menggunakan Shapiro Wilk [10]. Rumus Uji Normalitas menggunakan Shapiro Wilk adalah sebagai berikut:

$$
T_{3}=\frac{1}{D}\left[\sum_{i=1}^{k} a_{i}\left(X_{n-i+1}-X_{i}\right)\right]
$$

Dengan nilai D diperoleh dari

$$
\mathrm{D}=\sum_{\mathrm{i}=1}^{\mathrm{n}}\left(\mathrm{X}_{\mathrm{i}}-\overline{\mathrm{X}}\right)^{2}
$$

Dengan keterangan sebagai berikut

$$
\begin{array}{ll}
\mathrm{D} & =\text { Coefficient test } \text { Shapiro Wilk } \\
X_{n-i+1} & =\text { Angka ke } n-i+1 \text { pada data } \\
X_{i} & =\text { Angka ke }-i \text { pada data } \\
\overline{\mathrm{X}} & =\text { Rata-rata data }
\end{array}
$$

Selanjutnya menggunakan bantuan tabel Saphiro Wilk untuk nilai $\mathrm{T}_{3}$ yang diperoleh tadi dan dibandingakan dengan nilai level signifikan $(\alpha)$ yang kita pilih yaitu 0,05 . Pada penelitian ini perhitungan menggunakan bantuan software Statistika yaitu SPSS 26 untuk mendapatkan nilai signifikan pada uji Shapiro Wilk.

3. Jika kedua sampel berdistibusi normal, maka data akan diuji menggunakan uji Independen Sampel T [11]. Jika kedua sampel tidak berdistribusi normal, maka akan dilakukan uji Mann Whitney [12]. Uji tersebut dilakukan pada masing-masing kelompok mata kuliah.

Uji statistik Mann Whitney adalah sebagai berikut:

$\mathrm{U}=\mathrm{N}_{1} \mathrm{~N}_{2}+\frac{\mathrm{N}_{1}\left(\mathrm{~N}_{1}+1\right)}{2}-\mathrm{R}$

$\mathrm{N}=$ Nilai Mann Whitney

$\mathrm{N}_{1}$ = Banyak sampel pertama

$\mathrm{N}_{2}=$ Banyak sampel kedua

$\mathrm{R}=$ Jumlah jenjang sampel

Pada penelitian ini, uji Mann Whitney menggunakan bantuan SPSS 26.

4. Interpretasi data apakah ada perbedaan signifikan pembelajaran dengan video conference atau tidak pada masing-masing kelompok mata kuliah. 


\section{HASIL DAN PEMBAHASAN}

\section{A. Kelompok Mata Kuliah Bersama}

Pada kelompok mata kuliah bersama, setelah dilakukan uji kenormalan menggunakan Saphiro Wilk, salah satu sampel tidak berdistribusi normal. Berikut data Tabel 2 dari uji kenormalan menggunakan Saphiro Wilk dengan bantuan SPSS 26.

Tabel 2. Uji Normalitas Shapiro Wilk Pada Mata Kuliah Bersama

\begin{tabular}{llccc}
\hline & $\begin{array}{l}\text { Metode } \\
\text { Belajar }\end{array}$ & Statistik & $\begin{array}{c}\text { Uji Shapiro-Wilk } \\
\text { Derajat } \\
\text { Bebas }\end{array}$ & Signifikansi \\
\hline \multirow{2}{*}{$\begin{array}{l}\text { Hasil } \\
\text { Belajar }\end{array}$} & $\begin{array}{l}\text { Video } \\
\text { Conference }\end{array}$ & 0,900 & 20 & 0,040 \\
\cline { 2 - 5 } & E-belajar & 0,914 & 20 & 0,077 \\
\hline
\end{tabular}

Berdasarkan Tabel 2, df merupakan jumlah sampel data, dan data kurang dari 50 data. Dari hasil uji kenormalan Saphiro Wilk, kelompok sampel hasil belajar mahasiswa yang melakukan pembelajaran dengan video conference nilai Sig. 0,040 dimana nilai ini kurang dari 0,05, sehingga data tidak berdistribusi normal. Sedangkan kelompok sampel hasil belajar mahasiswa yang melakukan pembelajaran dengan Ebelajar nilai Sig. adalah 0,077 lebih besar dari 0,05, maka data berdistribusi normal. Karena ada salah satu sampel yang tidak berdistribusi normal, maka uji perbedaan rata-rata 2 sampel tidak berpasangan pada kelompok mata kuliah bersama ini dilakukan dengan Uji Mann Whitney menggunakan SPSS 26.

Tabel 3. Uji Mann Whitney Kelompok Mata Kuliah

\begin{tabular}{|c|c|c|c|c|}
\hline \multicolumn{5}{|c|}{ Bersama } \\
\hline \multicolumn{5}{|c|}{ Ranks } \\
\hline & $\begin{array}{l}\text { Metode } \\
\text { Belajar }\end{array}$ & $\mathbf{N}$ & $\begin{array}{l}\text { Mean } \\
\text { Rank }\end{array}$ & $\begin{array}{c}\text { Sum of } \\
\text { Ranks }\end{array}$ \\
\hline \multirow{2}{*}{$\begin{array}{l}\text { Hasil } \\
\text { Belajar }\end{array}$} & $\begin{array}{l}\text { Video } \\
\text { Conference }\end{array}$ & 20 & 18,70 & 374,00 \\
\hline & E-belajar & 20 & 22,30 & 446,00 \\
\hline & Total & 40 & & \\
\hline \multicolumn{5}{|c|}{ Test Statistics ${ }^{a}$} \\
\hline \multicolumn{5}{|c|}{ Hasil Belajar } \\
\hline \multicolumn{3}{|c|}{ Mann-Whitney U } & & 164,000 \\
\hline \multicolumn{3}{|c|}{ Wilcoxon W } & & 374,000 \\
\hline \multicolumn{3}{|l|}{$\mathbf{Z}$} & & $-0,980$ \\
\hline \multicolumn{3}{|c|}{ Asymp. Sig. (2-tailed) } & & 0,327 \\
\hline \multicolumn{3}{|c|}{ Exact Sig. [2*(1-tailed Sig.)] } & & $0,341^{\mathrm{b}}$ \\
\hline \multicolumn{5}{|c|}{ a. Grouping Variable: metode belajar } \\
\hline
\end{tabular}

Hipotesis nol $\left(\mathrm{H}_{0}\right)$ dalam uji Mann Whitney ini adalah tidak ada perbedaan hasil belajar kelompok dengan video conference dan E-belajar. Hipotesis alternatif $(\mathrm{Ha})$ pada penelitian ini adalah ada perbedaan hasil belajar pada 2 kelompok tersebut. Pengambilan keputusan pada uji ini adalah sebagai berikut:
1. Jika nilai signifikansi lebih kecil dari 0,05, maka Нa diterima

2. Jika nilai signifikansi lebih besar dari 0,05 , maka Ha ditolak

Dari hasil output uji Mann Whitney pada Tabel 3, nilai signifikansi sebesar 0,327, artinya lebih besar dari 0,05 sehingga Ha ditolak. Ini artinya tidak ada perbedaan hasil belajar pada kelompok mahasiswa yang melakukan pembelajaran dengan video conference dan E-belajar pada mata kuliah bersama. Hal ini juga terlihat dari rata-rata hasil belajar melalui video conference dan e-belajar berturut-turut 18,70 dan 22,32 yang selisihnya kecil.

\section{B. Kelompok Mata Kuliah Keahlian}

Hasil uji kenormalan menggunakan Saphiro Wilk pada mata kuliah keahlian adalah salah satu sampel tidak berdistribusi normal.

Tabel 4. Uji Normalitas Shapiro Wilk Pada Mata Kuliah Keahlian

\begin{tabular}{|c|c|c|c|c|}
\hline \multicolumn{5}{|c|}{ Tests of Normality } \\
\hline & \multirow{2}{*}{$\begin{array}{l}\text { Metode } \\
\text { Belajar }\end{array}$} & \multicolumn{3}{|c|}{ Shapiro-Wilk } \\
\hline & & Statistic & df & Sig. \\
\hline \multirow[t]{2}{*}{$\begin{array}{l}\text { Hasil } \\
\text { Belajar }\end{array}$} & $\begin{array}{l}\text { Video } \\
\text { Conference }\end{array}$ & 0,886 & 20 & 0,023 \\
\hline & E-belajar & 0,932 & 20 & 0,169 \\
\hline
\end{tabular}

Berdasarkan output Tabel 4, nilai signifikansi dari kelompok video conference adalah 0,023. Karena kurang dari 0,05 , data tidak berdistribusi normal. Sedangkan nilai sifnifikansi kelompok E-belajar adalah 0,169 dan data berdistribusi normal. Karena ada salah satu sampel tidak berdistribusi normal, maka dilakukan uji Mann Whitney.

Hipotesis nol, hipotesis alternatif, dan pengambilan keputusan serupa dengan hipotesis pada kelompok mata kuliah Bersama. Dari hasil output Uji Mann Whitney pada Tabel 5, nilai signifikansi sebesar 0,04 , lebih kecil dari 0,05 sehingga Ha diterima. Ini artinya ada perbedaan hasil belajar pada kelompok mahasiswa yang melakukan pembelajaran dengan video conference dan E-belajar pada mata kuliah keahlian. Hal ini berbanding lurus dengan melihat selisih rata-rata hasil belajar 2 kelompok ini, yaitu 24,24 dan 16,78. Hasil belajar mahasiswa menggunakan video conference lebih baik daripada pembelajaran mandiri melalui E-belajar.

Tabel 5. Uji Mann Whitney Kelompok Mata Kuliah Keahlian

\begin{tabular}{llccc}
\hline & \multicolumn{4}{c}{ Ranks } \\
\hline $\begin{array}{l}\text { Metode } \\
\text { Belajar }\end{array}$ & N & $\begin{array}{l}\text { Mean } \\
\text { Rank }\end{array}$ & $\begin{array}{c}\text { Sum of } \\
\text { Ranks }\end{array}$ \\
\hline $\begin{array}{l}\text { Hasil } \\
\text { Belajar }\end{array}$ & $\begin{array}{l}\text { Video } \\
\text { Conference }\end{array}$ & 20 & 24,23 & 484,50 \\
\cline { 2 - 5 } & E-belajar & 20 & 16,78 & 335,50 \\
\hline & Total & 40 & & \\
\hline
\end{tabular}




\begin{tabular}{lr}
\hline \multicolumn{2}{c}{ Test Statistics $^{\mathbf{a}}$} \\
\hline \multicolumn{2}{c}{${ }^{2}$} \\
\hline Mann-Whitney U & 125,500 \\
\hline Wilcoxon W & 335,500 \\
\hline $\mathbf{Z}$ & $-2,021$ \\
\hline Asymp. Sig. (2-tailed) & 0,043 \\
\hline Exact Sig. [2*(1-tailed Sig.)] & $0,043 \mathrm{~b}$ \\
\hline a. Grouping Variable: metode belajar & \\
\hline b. Not corrected for ties. & \\
\hline
\end{tabular}

Intepretasi data pada kelompok MKK ini berbanding lurus dengan hasil kuisioner seluruh mahasiswa STIKI yang dikumpulkan oleh unit kemahasiswaan STIKI tentang pembelajaran video conference di bulan Juli 2020. Dari 114 mahasiswa yang menjadi responden, 59,6\% mahasiswa menjawab tidak keberatan jika pembelajaran dilakukan dengan video conference. Menurut mereka pembelajaran melalui video conference lebih memudahkan dalam penyampaian materi, namun terkendala sinyal meski telah mendapat bantuan kuota dari pemerintah. Beberapa dari mereka juga menyatakan bahwa mereka kesulitan memahami materi yang memuat perhitungan jika hanya daring di E-belajar, seperti Statistika, Metode Numerik, Aljabar Linier, Matematika Diskrit, dan lain-lain, dimana pada penelitian ini mata kuliah tersebut masuk dalam kelompok mata kuliah bersama. Ini berbanding terbalik dengan hasil uji Mann Whitney pada kelompok mata kuliah bersama, yang menyatakan bahwa tidak ada perbedaan hasil belajar pada kelompok mahasiswa yang melakukan pembelajaran dengan video conference dan E-belajar.

Selanjutnya, peneliti mencari penyebab dari hasil interpretasi yang berbeda melalui rata-rata per kelompok mata kuliah dan kelompok sampel. Dari rata-rata hasil belajar, nampak bahwa nilai hasil belajar pada mata kuliah keahlian cukup bagus yaitu 82,1 pada kelompok video conference dan 77,55 pada kelompok E-belajar. Pada mata kuliah keahlian ini, mahasiswa lebih mudah memahami materi melalui video conference sesuai dengan uji Mann Whitney yang ditunjukkan pada Tabel 6. Hasil tersebut menunjukkan bahwa pembelajaran dengan video conference pada mata kuliah keahlian khususnya mahasiswa teknik informatika dapat meningkatkan motivasi belajar yang akhirnya dapat meningkatkan efektivitas pembelajaran [13].

Tabel 6. Rata-Rata Hasil Belajar Perkelompok Mata Kuliah dan Sampel

\begin{tabular}{|c|c|c|}
\hline $\begin{array}{c}\text { Kelompok Hasil } \\
\text { Belajar }\end{array}$ & Kelompok Sampel & $\begin{array}{l}\text { Rata- } \\
\text { Rata }\end{array}$ \\
\hline $\begin{array}{l}\text { Kelompok Mata } \\
\text { Kuliah Bersama }\end{array}$ & $\begin{array}{l}\text { Dengan Video } \\
\text { Conference }\end{array}$ & 49,25 \\
\hline & Dengan E-belajar & 55,33 \\
\hline $\begin{array}{l}\text { Kelompok Mata } \\
\text { Kuliah Keahlian }\end{array}$ & $\begin{array}{l}\text { Dengan Video } \\
\text { Conference }\end{array}$ & 82,1 \\
\hline & Dengan E-belajar & 77,75 \\
\hline
\end{tabular}

Sedangkan hasil belajar kelompok mata kuliah bersama, kedua rata-rata kelompok sampel tidak terlalu bagus dan selisihnya tidak terlalu jauh, yaitu 49,25 pada kelompok video conference dan 55,33 pada kelompok sampel E-belajar. Ratarata tersebut menunjukkan bahwa pembelajaran video conference ataupun E-belajar pada mata kuliah bersama khususnya mata kuliah Matematika tidak mempengaruhi hasil belajar. Hal ini disebabkan karena Matematika merupakan salah satu disiplin ilmu yang mempunyai karakteristik yang unik yang dipenuhi dengan konsep-konsep dari yang sederhana sampai dengan konsep yang kompleks dan abstrak [14] sehingga mahasiswa teknik mengalami kesulitan dalam pembelajaran Matematika [15].

\section{KESIMPULAN}

Dari hasil pembahasan di atas, dapat disimpulkan penggunaan video conference pada pembelajaran sinkronus berpengaruh terhadap hasil belajar namun tidak untuk semua mata kuliah. Jika dipandang dari jenis mata kuliah, tidak ada perbedaan rata-rata hasil belajar pada kelompok mata kuliah bersama baik pada pembelajaran video conference maupun melalui E-belajar karena rata-rata hasil belajar pada mata kuliah bersama sama-sama tidak bagus dan selisihnya tidak terlalu jauh. Mata kuliah bersama yang dikhususkan pada penelitian ini adalah mata kuliah Matematika. Namun demikian, ada perbedaan rata-rata hasil belajar pada kelompok mata kuliah keahlian pada pembelajaran video conference dan E-belajar. Rata-rata hasil belajar mahasiswa menggunakan video conference lebih baik daripada hasil belajar menggunakan E-belajar pada mata kuliah keahlian. Pembelajaran melalui video conference tidak selalu berpengaruh pada hasil belajar, namun ada beberapa faktor lain yang mempengaruhi, seperti tingkat kesulitan materi dan ketertarikan mahasiswa untuk mempelajari materi.

\section{REFERENSI}

[1] Worldometer. (2020). Covid-19 Coronavirus Pandemic. Diakses dari: https://www.worldometers.info/ coronavirus/\#countries pada tanggal 27 Desember 2020

[2] Desk, N. (2020). Jokowi Calls For 'Social Distancing' To Stem Virus Spread. Diakses dari:, https://www.thejakartapost.com/news/2020/03/15/joko wi-calls-for-social-distancing-to-stem-virusspread.html pada tanggal 15 Maret 2020.

[3] Hamadin, Nyeneng, I.D.P. \& Ertikanto, C. (2015). Pengembangan Media Pembelajaran Interaktif Berbasis Tik Dengan Pendekatan Saintifik. Jurnal Pembelajaran Fisika Universitas Lampung, Vol. 3(2).

[4] Anonim. (2020). Media Komunikasi dan Inspirasi: Jendela Pendidikan dan Kebudayaan Meringankan Beban dengan Bantuan Kuota Internet.

[5] Silitonga, Y. \& Eminency, D.V. (2012). Analisa Perbandingan Kualitas Belajar-Mengajar antara Metode Face to Face dan Video Conference. Jurnal Sistem Informasi, Vol. 4(2), pp. 477-487.

[6] Upshaw, B.A. (2019). The Effects of Video Conferencing As an Instructional Tool in the High School Spanish II Classroom [Disertasi]. Education Department, Carson- 
Newman University.

[7] Haqien, D. \& Rahman, A.A. (2020). Pemanfaatan Zoom Meeting untuk Proses Pembelajaran pada Masa Pandemi Covid-19. SAP (Susunan Artik. Pendidikan), Vol. 5(1).

[8] Rustaman, A.H. (2020). Efektivitas Penggunaan Aplikasi Daring, Video Conference Dan Sosial Media Pada Mata Kuliah Komputer Grafis 1 Di Masa Pandemi Covid-19. Jurnal Ilmu Sosial dan Pendidikan, Vol. 4(3), pp. 557-562.

[9] Ismawati, D. \& Prasetyo, I. (2020). Efektivitas Pembelajaran Menggunakan Video Zoom Cloud Meeting pada Anak Usia Dini Era Pandemi Covid-19. Jurnal Obsesi, Vol. 5(1), pp. 665-65.

[10] Raharjo, S. (2015). Cara Uji Normalitas Shapiro-Wilk dengan SPSS Lengkap. Diakses dari: https://www.spssindonesia.com/2015/05/cara-ujinormalitas-shapiro-wilk-dengan.html.
[11] Mann, P.S. (2013). Introduction Statistic 8th Edition. Wiley.

[12] Suyanto \& Gio, P.U. (2017). Statistika Nonparametrik Dengan SPSS, Minitab, dan R. Medan: USU Press

[13] Sasongko, D.B., Fatirul, N. \& Hartono. (2019). Pengembangan E-Learning dengan Video Conference untuk Pendukung Pembelajaran Informatika Terapan di Politeknik Kelautan dan Perikanan Sidoarjo. Jurnal Education and Development, Vol. 7(2), pp. 236-240.

[14] Anggraini, S. (2020). Analysis Students Difficulty Learning Discrete Mathematics. International Conference on Social, Sciences and Information Technology.

[15] Kusumaningrum, D.S. \& Lestari, S.A.P. (2019). Analisis Kesulitan Belajar Matematika Diskrit Mahasiswa Teknik Informatika. Jurnal Prisma, Vol. 8(2), pp. 96-110. 